\title{
Introduction: the socialization of international lawyers
}

\section{THE PREMISES: A COMMUNITARIAN APPROACH TO FOUNDATIONAL DOCTRINES AND ARGUMENTATIVE TECHNIQUES}

Although this may be a feeling sometimes more pronounced and accepted in other social sciences, ${ }^{1}$ the main purpose of any introduction is the disclosure, with as much self-awareness as possible, of the conceptual premises of the subsequent argument. Needless to say that complete awareness of one's conceptual premises is unattainable, if not a contradiction in terms. Indeed, self-reflectivity remains carried out according to structures that are inherited from tradition and for which full awareness is not always conceivable. ${ }^{2}$ Yet, it seems at least possible to shed light on one's (self-understanding of the) conceptual premises informing the study that follows. This is the object of the present introduction.

In the following chapters, international law is construed as an argumentative practice that articulates itself around a set of foundational doctrines, themselves deployed through a variety of argumentative techniques. According to this understanding, these doctrines and techniques are not considered to have a priori validity and are not postulated in the abstract. Rather they are thought of as being both constitutive and constituted by the community of international lawyers that is organized around international law. This means that, for the chapters that follow, acquiring the mastery of the foundational doctrines and argumentative techniques of international law is what socializes international lawyers as

1 In international relations literature, there is much more systematic depiction of one's concepts than in international law literature. This certainly does not mean there is more conceptual transparency. For some critical observations on the way in which international lawyers write and construct their arguments, see chapter 8 .

2 A. MacIntyre, Whose Justice? Which Rationality?, Duckworth, 1988, $352-3$, at 367 . 
much as those social international lawyers shape those foundational doctrine and argumentative techniques.

These elementary premises are all but controversial. ${ }^{3}$ Claiming that international law is an argumentative practice, albeit not always substantiated, ${ }^{4}$ is commonplace in contemporary international legal scholarship. ${ }^{5}$ Likewise, a large number of international lawyers, increasingly informed by insights of other social sciences, ${ }^{6}$ have come to accept the idea that foundational doctrines and argumentative techniques operate in a dialectical relation with their social environment, for doctrines and argumentative techniques, on the one hand, and international lawyers (and the community they constitute), on the other, are now held to be simultaneously constitutive of one another. ${ }^{7}$

Although the mutually nourishing and constituting relation between foundational doctrines and argumentative techniques of international law and the community of international lawyers is a rather simple idea, it leaves international lawyers with the possibility to look at a myriad of

3 As is argued by I. Venzke, international law as practice appears to be a compromise between the idea that law is the expression of the will of the speakers and the idea that law is the image of structural forces. I. Venzke, "Multidisciplinary Reflections on the Relationship between Professionals and The(ir) International Law" ESIL 2013/ 5th Research Forum: International Law as a Profession, Conference Paper No. 4/2013, pp. 1-2.

4 On this finding, see I. Venzke, "What Makes for a Valid Legal Argument? (Editorial)", 27 Leiden Journal of International Law (2014) (pp. 844-46). (He argues that while scholars and practitioners concur about the idea that international law constitutes an argumentative practice, they disagree on what they understand to be the nature of arguing.)

5 M. Koskeniemmi, "Law, Teleology and International Relations: An Essay in Counterdisciplinarity", 26, International Relations, 3, at 3; see also M. Koskenniemi, "Methodology of International Law", Max Planck Encyclopedia of Public International Law, para. 1.

6 On the pitfalls of the current craving for interdisciplinarity, see however, J. Klabbers, "The Relative Autonomy of International Law and the Forgotten Politics of Interdisciplinarity" 1 Journal of International Law and International Relations 35; see also M. Koskenniemi, "Constitutionalism as Mindset: Reflections on Kantian Themes about International Law and Globalization", 8 Theoretical Inquiries in Law (2006) 9, at 14; M. Koskenniemi, "The Mystery of Legal Obligation", 3 International Theory (2011), 319-25, at 319. For some additional observations, see below chapter 6 .

7 For an application of the idea that structures produce agents while also being the product of agents, see T.J. Berard, "Rethinking Practices and Structures" (2005) 35 Philosophy of the Social Sciences 196-230; A. Giddens, Central Problems in Social Theory. Action, Structure and Contradiction in Social Analysis (Macmillan, 1979), 69. 
different facets of international law and international legal practice. In other words, if approached according to the abovementioned dialectical model, international law still lends itself to many different types of inquiries. One can grapple with the dialectics themselves and zero in on how output and input structuring dynamics coexist and interact in the formation of foundational doctrines and argumentative dynamics and how they impact on the international society. This approach would be mostly of a sociological character, necessitating the resort to tools and methods of other social sciences. This is not the approach favored in this study that consciously focuses mostly on one single aspect of these dialectical dynamics. This book makes a decided communitarian turn and zeroes in on the way the community of international lawyers conditions the doctrines and argumentative techniques of international lawyers. This communitarian approach - which is not without constructivist overtones ${ }^{8}$ - informs the majority of the chapters that follow. Said differently, the bulk of this book is devoted to the way in which (and the reasons informing how) the community of international lawyers designs the foundational doctrines of international law and uses argumentative techniques. Thus, this book is primarily an exploration of how the community of international lawyers impacts the way in which those doctrines and techniques are cast and deployed in contemporary legal scholarship and practice.

This is not to say that this book turns a blind eye to the other facet of the mutually-nourishing relation between foundational doctrines and argumentative techniques on the one hand and the community of scholars on the other. It seems difficult to study one facet without showing minimal awareness for the other. This is why, while the rest of the book explores the communitarian dynamics at works in the design of doctrine and the deployment of argumentative techniques, this introduction concentrates on the way in which foundational doctrines and argumentative techniques socialize international lawyers and determine both their identity and that of the community they constitute.

8 See e.g. N. Rajkovic, "Rules, Lawyering, and the Politics of Legality: Critical Sociology and International Law's Rule", 27 Leiden Journal of International Law (2014), 331-52. 


\section{THE OBJECT OF THE INQUIRY: INTERNAL AND FUNCTIONAL SITUATIONALISM}

Approaching international law from a communitarian perspective is hardly unheard of, especially since the second half of the twentieth century. ${ }^{9}$ Since French sociology made its first foray into international legal studies, international lawyers have grown aware that arguing, studying, and invoking international law constitute highly structured activities in the sense that the juridical field is permeated by social structures which directly impinge on the production of the legal discourse. ${ }^{10}$ The idea that applying international law is embedded within a social context pervaded by "highly rationalized struggles" between jurists, each competing to construct an "official representation of the social world"11 is no longer controversial. International lawyers have also learnt from French sociologists that power not only comes in forms of centralized constraints but is dispersed, ubiquitous and even at work in the production of reality. In that sense, they know too well that arguing about international law is an exercise of power aimed at objectifying particular modes of thought and normalizing formal and informal modes of social ordering. ${ }^{12}$

Notwithstanding being clearly informed by some of these sociological insights - some of which are spelled out in this Introduction, it must be repeated that this book is not a sociological exercise seeking to shed light

9 I. Venzke argues that theories that give prime consideration to the concept of practice have for a while been mainly structuralist (and mainly Marxist). See I. Venzke, "Contemporary Theories and International Law Making", Amsterdam Centre for International Law No. 2013-23, at 18.

10 This is one of the central ideas defended by Bourdieu in his studies of the legal field. See e.g. P. Bourdieu, "The Force of Law: Toward a Sociology of the Juridical Field" 38 Hastings Law Journal (1987) 805-53.

11 Ibid., 805-53, at 805.

12 On the step made between Bourdieu and Foucault and the distinct benefits of the insights provided by each of them for the study of international law, see the remarks of N. Rajkovic, "Rules, Lawyering, and the Politics of Legality: Critical Sociology and International Law's Rule", 27 Leiden Journal of International Law (2014), 331-52, at 341. N. Rajkovic, "Rules, Lawyering, and the Politics of Legality: Critical Sociology and International Law's Rule", 27 Leiden Journal of International Law (2014), 331-52, at 341, citing V. Tadros, "Between Governance and Discipline: The Law and Michel Foucault" (1998), 18 Oxford Journal of Legal Studies, 75, at 78; see also F. Ewald, "Norms, Discipline and the Law" (1990), 30 Representations 138, at 139-41; A Foucauldian Approach to International Law. Descriptive Thoughts for Normative Issues, by L.M. Hammer. Aldershot: Ashgate, 2007. 
on the structural characteristics of the field and bring to the surface the exercise of power behind the production of knowledge. The ambition of this book lies elsewhere. It is not that the structures of the field are not worthy of investigation by international lawyers. Understanding those structures certainly helps explain why international legal thinking continues to oscillate between contradictory paradigms and eternally moves in circles, often in opposite terms. ${ }^{13}$ Likewise, identifying those very structures that obfuscate the exercises of power constitutes a concern which international legal thinkers have rightly engaged with in recent years. ${ }^{14}$ Yet, this book sets itself more modest ambitions and rather focuses on another aspect of the communitarian dimension of the argumentative practice of international law which has been, to the knowledge of this author, rarely explored in contemporary legal scholarship.

The chapters that follow approach foundational doctrines and argumentative techniques as distinct tools to impose social arrangements within and beyond the field. The social arrangements contemplated by foundational doctrines and argumentative techniques under examination here can often pertain to the organization of the "outside world" as much as that of the community of international lawyers itself. The social arrangement promoted by foundational doctrines and argumentative techniques can thus be of an internal or external nature. This book does not seek to unearth the social arrangements that the foundational doctrines and argumentative techniques under examination here seek to vindicate. This would reduce this book to another study of the "politics" of international law aimed at unveiling the external agenda of doctrines and argumentative techniques. Instead, the chapters that follow limit themselves to functionally situate the design of foundational doctrines and the deployment of argumentative techniques in relation to the community of international law itself, irrespective of the political agenda that is envisaged for the external world. The

13 D. Kennedy, "When Renewal Repeats: Thinking Against the Box", 32 New York University Journal of International Law and Politics 335 (2000). For some nuances to the idea that the legal scholarship moves as a pendulum, N. Duxbury, Patterns of American Jurisprudence, OUP, 1997, at 2-4.

14 Others like M. Koskenniemi have taken direct issue with those structures, like managerialism, in that they obscure the way power works. See M. Koskenniemi, "The Politics of International Law: 20 Years Later" 20 European Journal of International Law (2009) 7-19. This is why his culture of formalism seeks to reinstate international law as the only available surface over which managerial governance may be challenged. M. Koskenniemi, The Gentle Civilizer of Nations: The Rise and Fall of International Law 1870-1960 (Cambridge University Press, 2002), at 500-508. 
exercise, in contrast with numerous contemporary studies, is thus neither problem-solving nor complexity-reducing. ${ }^{15}$ Its ambitions lie solely with shedding light on the internal social arrangements that are pursued by international lawyers when designing and deploying their foundational doctrines and argumentative techniques. It is inevitable, however, that in discussing internal social arrangements pursued by the community of international lawyers, the chapters below occasionally touched on the external social arrangements eyed by international lawyers. This, however, is never the primary focus of the inquiry.

The foregoing should suffice to show that this book, rather than a detour into the sociology of international law or the politics of international law, primarily constitutes an exercise of functional and internal situationalism. ${ }^{16}$ Indeed, its aim is to internally contextualize the making and deployment of the foundational doctrines and argumentative techniques by exhuming the conditions that influence the limits and potential to which their architects and users are subjected. ${ }^{17}$ Needless to say that exploring the situatedness of (the design or deployment of) foundational doctrines and argumentative techniques is nothing groundbreaking in contemporary scholarship. It is certainly the legacy of critical legal studies - although they were no pioneer in this respect - to have taught international lawyers exposed to it, and especially international legal scholars, not only to disclose their own agenda and conceptual premises, but also to try to situate the legal claims of others. ${ }^{18}$ In today's international legal scholarship, the situatedness of legal claims and legal argument has even become a central object of inquiry.

It is well known that situatedness of an argument inextricably has multiple facets. One can situate a legal claim from a great variety of angles: anthropological, cultural, historical, traditional, political, socioeconomical, socio-historical, etc. It seems fair to say that the mainstream

15 On the necessity of legal scholarship to reduce complexity, see A. Peters, "Realizing Utopia as a Scholarly Endeavor", 24 European Journal of International Law (2013) 533-52.

16 For an early elaboration of situationality, see K. Jaspers, The Future of Mankind, 1958 (transl) and Man in the Modern Age, 1932 (transl) (Berlin, 1932).

17 O. Korhonen, International Law Situated. An Analysis of the Lawyer's Stance Towards Culture, History and Community, The Hague; London: Kluwer Law International (2000), 8.

18 Situationalism was very central in legal realism. On the link between critical legal studies and legal realism, see N. Duxbury, Patterns of American Jurisprudence, OUP, 1997, at 6. 
approach to situatedness in today's international legal scholarship is probably socio-historical and it seems no coincidence that one of the most seminal pieces of scholarship produced in the present century sought to situate international law within its socio-historical context. ${ }^{19}$ As the foregoing has already indicated, this book departs from the main type of situationalism observed in the international legal literature and shies away from embarking on a discussion of the socio-historical situatedness of foundational doctrines and techniques considered below. Rather, this book construes the foundational doctrines and argumentative techniques of international law as purposive constructions and activities ${ }^{20}$ and seeks to unearth the internal social arrangements that are pursued in the design and deployment of each of them.

It must be acknowledged that situationalism, albeit growing more common in international legal studies, is certainly not without problem. It is inevitably affected by self-referentiality, ${ }^{21}$ and, in the context of socio-historical situationalism, an anachronism. ${ }^{22}$ Indeed, the insights produced by situationalism are inevitably prejudiced by the preunderstandings of the one exploring the situatedness of any legal claim. ${ }^{23}$ This is why it is acknowledged that situationalism is itself necessarily situated. ${ }^{24}$ Those problems have, however, been deemed insurmountable,

19 See generally M. Koskenniemi, The Gentle Civilizer of Nations (CUP, 2001). See the remarks on this aspect of M. Koskenniemi's project by J. Dunoff, "From Interdisciplinarity to Counterdisciplinarity: Is there Madness in Martti's Method?", 27 Temple International and Comparative Law Journal 309 (2013).

20 This is certainly not ground-breaking. It is well-known that contemporary natural law thinkers construe law as a purposive enterprise. See L. Fuller, The Morality of Law (Yale University Press, 1964 second edition, 1969), p. 145. For an application to international law, see P. Capps, Human Dignity and the Foundations of International Law, Hart, 2009, 41-3.

21 See the criticism of Fish's situatedness of interpretation and the de-reponsibilization of the self by P. Shlag. See P. Shlag, "Fish v. Zapp: The Case of the Relatively Autonomous Self", 76 The Georgetown Law Journal (1987) 36.

22 On the problem of anachronism in socio-historical situationalism, see the comments and rebuttal by M. Koskenniemi, "Histories of International Law: Significance and Problems for a Critical View" 27 Temple Journal of International and Comparative Law (2013) 215.

23 See O. Korhonen, (2000), International Law Situated. An Analysis of the Lawyer's Stance Towards Culture, History and Community, The Hague; London: Kluwer Law International, pp. 9-10.

24 Stanley Fish, Is there a text in this class? Harvard University Press, 1980, 360; see also A. MacIntyre, Whose Justice? Which Rationality?, Duckworth, 1988,367 . In the context of legal argumentation, O. Korhonen recalls that critical 
played down or turned on their head as a source of richness for scholarly inquiries. ${ }^{25}$ It is not necessary to address them here. It seems more relevant to formulate a few additional caveats on the scope and purpose of the chapters that follow.

First, it should go without saying that determining one or several dimensions of the situatedness of a legal claim or legal argument does not make the claim or argument concerned more determinate as far as its substance is concerned. ${ }^{26}$ In that sense, this book does not constitute an attempt to rein in the indeterminacy that inevitably shrouds the foundational doctrines of international law and that is unavoidably exacerbated by the deployments of the argumentative techniques of international lawyers. ${ }^{27}$ Second, although they focus on the functional situatedness of the foundational doctrines of international law and the argumentative techniques deployed by international lawyers, the following chapters do not reduce doctrines and argumentative techniques to the choices of their architects or the social arrangements they contemplate. Likewise, this book should not be understood as an exercise of critical narrative analysis properly so called as this commonly requires an in-depth and systematic exploration of the various components of legal arguments. ${ }^{28}$ The following chapters, as was explained above, limit themselves to the functional intellectual manoeuvres behind the design of foundational doctrines and the deployment of argumentative techniques. Third, as these chapters will make clear, the social arrangements contemplated by international lawyers when designing and deploying their foundational doctrines and argumentative techniques can very well be

method is not an ultimate universally valid method but also a form of submission to structure. See O. Korhonen, "New International Law: Silence, Defence or Deliverance?" 7 European Journal of International Law (1996), 1-28, 17.

25 On the virtues of anachronism, see K. Koskenniemi, "Histories of International Law: Significance and Problems for a Critical View", 27 Temple Journal of International and Comparative Law (2013) 215, at 230-31.

26 O. Korhonen, "New International Law: Silence, Defence or Deliverance?" 7 European Journal of International Law (1996), 1-28, at 5.

27 It is an exaggeration to claim that this was the purpose of my previous work on the role of formalism and the sources of international law. I thus disagree with the reading of S. Singh, "Appendix 2: International Law as a Technical Discipline: Critical Perspectives on the Narrative Structure of a Theory" (May 26, 2013) in J. d'Aspremont, Formalism and the Sources of International Law (Oxford: OUP, 2013), pp. 236-61; University of Cambridge Faculty of Law Research Paper No. 22/2013

28 See the critical remarks by S. Singh, "International Law as a Technical Discipline: Critical Perspectives on the Narrative Structure of a Theory", ibid. 
unconscious. International lawyers may be mechanically reproducing narratives or methods through which they have been socialized without realizing the social arrangements envisaged by each of them. The (un)conscious character of the pursuit of social arrangements is, to some extent, irrelevant here, especially since the self-consciousness of international lawyers - albeit inevitably part of the social structures looked at - is not the primary object of the essays that follow. ${ }^{29}$ Fourth, it should be made clear that approaching the practice of international law in communitarian terms does not mean that the community of international lawyers must itself be held a formal source of law. ${ }^{30}$ Foundational doctrines and argumentative techniques are not approached from the perspective of the sources of international law. Neither is their validation by virtue of the mainstream doctrine of sources an object of inquiry. Of singular interest here is the pursuit of internal social arrangements by international lawyers when designing and deploying their foundational doctrines and argumentative techniques, irrespective of their implications for (and from the perspective of) the doctrine of sources of international law.

\section{THE SOCIALIZING OF INTERNATIONAL LAWYERS THROUGH THE ACQUISITION OF FOUNDATIONAL DOCTRINES AND TECHNIQUES}

As was indicated in the previous section, this book adopts a communitarian approach to the relation between foundational doctrines and argumentative techniques and the community of international lawyers by examining the way in which the community of international lawyers impacts the design and the use of foundational doctrines and argumentative techniques. It particularly looks at the internal functional situatedness of the design and use of such foundational doctrines and argumentative techniques and seeks to exhume some of the social arrangements pursued by international lawyers on such occasions. So delineated, the object of inquiry of the chapters that follow obviously presupposes that there is

29 For such an inquiry, see M. Koskenniemi, "Between Commitment and Cynicism: Outline for a Theory of International Law as Practice" in The Politics of International Law, Hart, 2011, at 271.

30 On this debate, see gen. J. Kammerhofer, "Law-Making by Scholars" (November 30, 2012). C. Brölmann and Y. Radi (eds), Research Handbook on the Theory and Practice of International Law-Making (Cheltenham: Edward Elgar 2015) (forthcoming). 
such a thing as a community of international lawyers to which consciousness and instrumental choices can be attributed. In other words, it presupposes that international lawyers naturally have coalesced into a community sharing some consciousness or disciplinary sensitivity and are capable of pursuing common social arrangements. And this is where this book, although it focuses primarily on the way communitarian dynamics informs the design and use of foundational doctrines and argumentative techniques, must turn its attention to the way in which those doctrines and techniques themselves shape the community of international lawyers.

The idea of a community of international lawyers is apprehended here through the notion of socialization. It is the process of socialization that makes individual agents coalesce into a collective association and become a member thereof. The notion of socialization is also what reveals the extent of the implications of the abovementioned dialectical understanding of the relation between foundational doctrines and argumentative techniques on the one hand and the community of international lawyers on the other. The socialization of international lawyers, as it is understood here, refers to international lawyers, despite diverging political commitment becoming possessed with certain doctrines as well techniques of reading and using the law. ${ }^{31}$ In other words, becoming an international lawyer is to undergo a process of socialization whereby one is trained to the doctrines and argumentative techniques of international law, and more generally, to the "world view" of the discipline. ${ }^{32}$ From the perspective of the process of socialization, the foundational doctrines and argumentative techniques can be considered a "grammar"33 common to all international lawyers that determines what it is possible to say, to think and to hope with the language of international law. Said differently, through socialization, international lawyers are introduced to those rituals that function as symbolic validation mechanisms. ${ }^{34}$ It is true that, from a more empirical perspective, it could be contended that a community of international lawyers could exist in the

31 See the critical remarks of P. Bourdieu, "The Force of Law: Toward a Sociology of the Juridical Field" 38 Hastings Law Journal (1987) 805-53, at 827.

32 O. Korhonen, "New International Law: Silence, Defence or Deliverance?" 7 European Journal of International Law (1996), 1-28, at 6.

33 M. Koskenniemi, From Apology to Utopia, CUP, 2005, p. 589 ("a grammar is not a description of what native language-speakers say in fact - it is an account of what it is possible to say in that language").

34 T. Franck, The Power of Legitimacy among Nations, NY, OUP, 1990, p. 92 . 
absence of international law. ${ }^{35}$ Yet this book departs from such an empirical finding and embraces a notion of community whereby the foundational doctrines and argumentative techniques feed into the socialization process of international lawyers and allow the emergence of a consciousness that is itself constitutive of the community.

The point made here is thus that the acquisition of these foundational doctrines and argumentative techniques contributes to the socialization of international lawyers (and allows them to coalesce into a community) because it gives rise to a shared consciousness, understood here as a vocabulary of concepts and typical arguments ${ }^{36}$ or some disciplinary sensitivity. ${ }^{37}$ Here too there exists a myriad of different descriptive frameworks to apprehend the consciousness or sensitivity constitutive of the community. Some scholars have spoken of mindset or tradition. ${ }^{38}$ Others have referred to the notions of cultural unity, ${ }^{39}$ ethos, ${ }^{40}$ legal culture, ${ }^{41}$ normative universe (nomos), ${ }^{42}$ or collective consciousness. ${ }^{43}$

35 As J. Crawford put it when receiving the ASIL Hudson Medal (2012): "One does not need to believe in God to credit the existence of the clergy", 106 ASIL Proceedings 2012, p. 2). See also the critical remarks of J. d'Aspremont, International Lawyers Live! (May 23, 2013). Available at SSRN: http://ssrn.com/ abstract $=2271115$.

36 Duncan Kennedy, "Two Globalizations of Law and Legal Thought: 1850-1968”, 36 Suffolk University Law Review (2003), 631, at 634.

37 David Kennedy, "The Disciplines of International Law and Policy" 12 Leiden Journal of International Law 9-133 (1999), at 13 and 17.

38 M. Koskenniemi seems to be using these words interchangeably. See M. Koskenniemi, "Constitutionalism as Mindset: Reflections on Kantian Themes about International Law and Globalization", 8 Theoretical Inquiries in Law (2006) 9 , at 9.

39 M. Prost, The Concept of Unity in Public International Law (Hart, 2012), pp. 153 and 159 (who refers to the "parameters for the product, the dispersion and the validation of juridical discourse" and argues that international law can be studied like any other cultural system).

40 F. Megret, International Law as Law (September 6, 2010). Cambridge Companion to International Law, J. Crawford and M. Koskenniemi, eds, 2010, 64 , at 66.

41 See H.P. Glenn, Legal Traditions of the World, OUP, 2007 (putting the emphasis on the idea of continuity).

42 R. Cover, The Supreme Court 1982 Term - "Foreword: Nomos and Narrative" 97 Harvard Law Review 4, at 4-5 (1983) (putting the emphasis on the whole normative corpus of a living community by virtue of which a community constitutes a community).

43 E. Durkheim, The Division of Labor in Society, Glencoe, The Free Press, (1947), pp. 79-80 (who speaks of social psyche constituted by a group with common beliefs and sentiments). 
Needless to say that the consciousness or disciplinary sensitivity constantly evolves over time, together with the foundational doctrines and argumentative techniques. It is a dynamic cognitive notion meant to capture a fluid factual phenomenon. By definition, it is inconceivable to apprehend (and delineate) what the consciousness of the discipline is at any moment in time. At best, one can represent, with broad strokes, what the mainstream understanding(s) of the foundational doctrines as well as what the mainstream use(s) of the argumentative techniques look like. The textbooks and the scholarship can constitute good indicators in this respect. ${ }^{44}$ However, this book should certainly not be perceived as attempting, in any way, to provide a plain account of what is the consciousness or disciplinary sensitivity of the time.

Socialization occurs through visible (and conscious) and less-visible (and unconscious) channels. It would be of no avail to discuss them extensively here. It suffices to focus on two of the main mechanisms through which socialization is realized: education and scholarship. ${ }^{45}$ It does not seem controversial to claim that training and education constitute the main instrument through which international lawyers are socialized, that is made proficient in the language of international law and acquire a consciousness shared with all those that have been trained the same way. Although there are significant geographical variations, ${ }^{46}$ the

44 For instance contemporary scholarship seems to indicate that, probably as a result of the rise and success of critical legal studies and deconstructivism in international legal thinking, the shared consciousness of international lawyers nowadays include self-doubt. For an elaboration on this theme, see generally M. Koskenniemi, "Between Commitment and Cynicism: Outline for a Theory of International Law as Practice" in The Politics of International Law, Hart, 2011, at 271 .

45 One could also think of the socialization that occurs by virtue of professional training in law firms, legal services of foreign affairs ministries or legal divisions of international organizations.

46 Although this comes with a bit of oversimplification, it is commonly believed that, in the Anglo-Saxon tradition, the emphasis is first put on the acquisition of skills whereas, in civil law traditions and others, the focus is on the acquisition of knowledge. On this debate, see gen. M. Damaska, "A Continental Lawyer in an American Law School: Trials and Tribulations of Adjustment", 116 University of Pennsylvania Law Review (1968) 1363. See also H. Dagan, "Law as an Academic Discipline", Tel Aviv University Law School, Tel Aviv University Law Faculty Papers, Paper 171, (2013). Available at SSRN: http://ssrn.com/ abstract $=2228433$. In recent years, some concern arises as a result of the move to interdisciplinarity, not only in legal scholarship, but also in legal education. See Weinrib, "Can Law Survive Legal Education" 60 Vanderbilt Law Review (2007) 401, at 403-4 and 410-11. 
socialization of international lawyers through education and training is usually realized by virtue of a transmission of both knowledge (including foundational doctrines) and skills (including argumentative techniques). ${ }^{47}$ In that specific mode of socialization, textbooks play a crucial formatting role. ${ }^{48}$ Although education and training are two of the most powerful instruments of socialization, one should not underestimate the role played by scholarship in the process of acquisition of the doctrines and argumentative techniques of international law. Indeed, both the consumption of scholarship (as a reader) and the production of scholarship (as an author) contribute to the rise of a shared consciousness or disciplinary sensitivity. This does not seem controversial and hence does not call for any discussion here.

Whatever the channels of socialization may be, it seems unanimously recognized that they contribute to the reproduction of the very powerful structures of the field. This is a finding long made by sociologists ${ }^{49}$ and it is now uncontested among international lawyers that the foundational doctrines as well as the argumentative techniques acquired through socialization processes open new argumentative spaces as much as they restrict them. ${ }^{50}$ Those structures affect both the access to socialization as well as access to the community of socialized international lawyers. In that sense, it should be emphasized that, as a result of those powerful structures, socialization cannot be deemed synonymous to access to legal argumentation itself. Being socialized as an international lawyer does not necessarily provide access to authoritative and universal legal argumentation. Access to legal argumentation remains restricted. Not everyone is allowed to have their legal argumentation even considered. Being admitted as an authorized interpreter of international law - and thus deploying

47 For G. Simpson, socialization through education and training is carried out in a "romantic" way, that is, by virtue of a series of compromises (or repressed theoretical contradictions). See Gerry Simpson, "On the Magic Mountain: Teaching Public International Law", 10 European Journal of International Law 1999, 70-92, 72.

48 For some critical remarks, see the special symposium in the European Journal of International Law in "Symposium: A Colloquium on International Law Textbooks in England", 11 European Journal of International Law (2000) 615.

49 See P. Bourdieu, "The Force of Law: Toward a Sociology of the Juridical Field" 38 Hastings Law Journal (1987) 805-53.

50 J. Crawford and M. Koskenniemi, "Introduction", in J. Crawford and M. Koskenniemi (eds), Cambridge Companion to International Law (CUP, 2012), at 4; see also M. Koskenniemi, From Apology to Utopia, CUP, 2005, p. 589. 
foundational doctrines and argumentative technique - is not a universal entitlement and is dependent on other - formal and non-formal parameters. While access to socialization itself is restricted - especially when it materializes in the taking of an advanced university degree access to legal argumentation will thereafter depend, among others, on one's affiliation or profession. ${ }^{51}$ This is not to mention exclusion by power and practical constraints. These entry tariffs to legal argumentation vary according to the fragmentation of the community of the community of international lawyers. ${ }^{52}$ The socialization discussed here should thus not be understood as seeking to open a "horizon" of a universal legal argumentation, as this has been yearned for by some international lawyers. 53

It is probably not necessary to elaborate on those powerful enabling and restricting structures that bear upon the access to the socialization process and the access to the community of socialized international lawyers. One remark must however be made about the idiom in which

51 To illustrate that point, it suffices to recall how suspicious we are when we open a book, an article or a working paper from someone whose name is unknown to us and who does not provide his or her professional affiliation. In such a case, and unless it comes with the recommendation of trustworthy peers or a very sexy title, there is a high chance that we do not even bother to read it. This is also why it always proves so important to mention one's affiliation on open access repositories and databases like SSRN.

52 As a result, there exist various - sometimes overlapping - guilds, each of them with different entry tariffs for potential entrants. For some critical remarks, see A. Rasulov, "New Approaches to International Law: Images of a Genealogy", in J.M. Beneyto and D. Kennedy (eds), New Approaches to International Law: the European and the American Experiences (TMC Asser-Springer, 2012), pp. 151-91.

53 This is the famous concept of "culture of formalism" floated by M. Koskenniemi. M. Koskenniemi, The Gentle Civilizer of Nations: The Rise and Fall of International Law 1870-1960 (Cambridge University Press, 2002), at 500-508. For a discussion of that concept, see E. Jouannet, "Présentation critique", in M. Koskenniemi, La Politique du Droit International (Paris, Pedone, 2007), at 32-3. See also I. de la Rasilla del Moral, "Martti Koskenniemi and the Spirit of the Beehive in International Law", 10 Global Jurist (2010); J. von Bernstorff, "Sisyphus was an international lawyer. On M. Koskenniemi's 'From Apologia to Utopia' and the place of law in international politics", 7 German Law Journal (2006) 1015, at 1029-31; J.A. Beckett, "Rebel Without a Cause. M. Koskenniemi and the Critical Legal Project", 7 German Law Review (2006) 1045; see also the book review of M. Koskenniemi, "The Gentle Civilizer of Nations: The Rise and Fall of International Law 1870-1960" by N. Tsagourias, 16 Leiden Journal of International Law (2003) 397, pp. 398-9. 
nowadays most of the abovementioned socialization occurs, be it through education and training or scholarship. Indeed, the dominant language in which international law is today taught and thought, not to say argued, has itself generated its own sets of enabling and restricting structures. With the rise of the English language as the lingua franca of international law $^{54}$ come a style of analysis and specific categories as well as a worldview, even for those for whom English is not a mother tongue. ${ }^{55}$ This has not been without consequences on the distribution of power among international lawyers. Although they are today surrounded by an overwhelming majority of non-native speakers practicing international law in English, native speakers necessarily continue to enjoy some ascendency 56 and are more in a position to impose their categories, methods, cognitive frameworks, style, and to some extent, views of the discipline and views of the world.

There are of course many more structures that bear upon the socialization process of international lawyers and the access to the community of socialized international lawyers. Some of them will be touched upon in the following chapters.

\section{THE COMMUNITY OF SOCIALIZED INTERNATIONAL LAWYERS: EPISTEMIC COMMUNITY, COMMUNITY OF PRACTICE, INTERPRETIVE COMMUNITY OR COMMUNICATIVE COMMUNITY?}

As the previous section has shown, it is through socialization that the international lawyers coalesce into a community. It is by acquiring, among others, these doctrines and argumentative techniques, that they come to form a community - that community, in turn, impacting on how foundational doctrines and argumentative techniques operate. The community of international law that emerges through the socialization process briefly described above can of course be apprehended in a great

54 For some similar observations, see A. Somek, "The Indelible Science of Law", University of Iowa Legal Studies Research Paper, Number 09-18, June 2010.

55 Ibid., at 79.

56 For a similar finding albeit in another context, see M. Koskenniemi, "Miserable Comforters: International Relations as New Nature Law", 15 European Journal of International Relations (2009) 395-422, at 395. 
variety of ways. Until recently, international lawyers would only look at the community organized around international law through the angle of law-appliers, ${ }^{57}$ auctoritatis interpositio, ${ }^{58}$ or those undeveloped - but not unpopular - notions like the invisible college. ${ }^{59}$ In recent years, however, other cognitive models have come to stand out, some of which have been inherited from other social sciences. It suffices to mention four of them briefly. ${ }^{60}$

First, from international relations theory, international lawyers have learned that their community could be understood as an epistemic community, that is in a non-systematically organized network of professionals with recognized expertise and authority that allow them to contribute to the making of policy-relevant knowledge in relation to their area of expertise. ${ }^{61}$ According to this construction, international lawyers constitute an epistemic community, and thus not merely an interest group, or a social movement by virtue of a shared faith in certain -

57 The notion of law-applier emerged in the context of a rule-based approach to international law. It finds roots in British analytical jurisprudence as well as German legal positivism. It quickly proved insufficient as it often remained equated with the idea of judicial authority. In recent years, the concept of law-applying authority has been subject to some dilution and pluralization in general theory of law and jurisprudence. See K. Culver and M. Giudice, Legality's Borders - An Essay in General Jurisprudence, OUP, 2010.

58 The idea of auctoritatis interpositio is borrowed from C. Schmitt although it is used to refer to the Kantian idea - systematized by Kelsen - that by virtue of the indeterminacy of rules law is ultimately dependent upon human judgement. See C. Schmitt, Politische Theologie: Vier Kapitel zur Lehre von der Souveränität ((Berlin: Duncker und Humblot, 1979), at 41. See the discussion of that question by N. Rajkovic, "Rules, Lawyering, and the Politics of Legality: Critical Sociology and International Law's Rule", 27 Leiden Journal of International Law (2014), 331-52

59 O. Schachter, "The Invisible College of International Lawyers" $72 \mathrm{Nw} . \mathrm{U}$. L. Rev. 217 (1977-1978).

60 The inquiry here is thus alien to an examination of the distinctiveness of the community of lawyers within the society as a whole. For a discussion of the various parameters that allow a differentiation between the community of lawyers and the rest of the society, see, F. Schauer, The Force of Law (Harvard University Press, forthcoming 2015), chapter 11. See more generally N. Luhmann, The Differentiation of Society, New York: Columbia University Press, 1984. See also Luhmann, Das Recht der Gesellschaft, Frankfurt a.M. 1995, 550 ss. (Engl.: Law as a Social System, Oxford, OUP, 2004).

61 P. Haas, "Introduction: epistemic communities and international policy coordination", 46 International Organizations (1992) 1, at 2 and 3 (Peter Haas acknowledged that the notion has some Marxist origins but that he uses it in a different way). 
allegedly scientific - methods as a way of generating truth. ${ }^{62}$ The notion of epistemic community has proved rather appealing for many international lawyers to explain some of the dynamics at work in the creation of knowledge about international law. ${ }^{63}$

Second, from another strand of international relations, international lawyers have borrowed the more fluid and open idea of community of practice. According to such a construction, international lawyers constitute a community of practice as long as they "are informally as well as contextually bound by a shared interest in learning and applying a common practice" 64 while also sharing a common "repertoire of communal resources, such as routines, words, tools, ways of doing things, stories, symbols, and discourse".65 This presupposes "social communication through which practitioners bargain about and fix meanings and develop their own distinctive identity and how to practice it". ${ }^{66}$ The concept of community of practice is more fluid in that the members' shared sense of joint enterprise is constantly being renegotiated ${ }^{67}$ and membership is not fixed as members constantly move in and move out. ${ }^{68}$ Notwithstanding some inevitable incommensurable elements that distort any comparison between the two notions, it seems possible to say, with a good deal of oversimplification, that communities of practice constitute a more all-encapsulating notion than that of epistemic community, the latter being a special kind of community of practice. Like the notion of epistemic community, the notion of community of practice has found an echo in international legal scholarship, the doctrine of sources being

62 Ibid. at 3 and at 18.

63 M. Noortmann, "The International Law Association and Non-state Actors: Professional Network, Public Interest Group or Epistemic Community?", in J. d'Aspremont (ed.), Participants in the International Legal System: Multiple Perspectives on Non-state Actors in International Law (Routledge, 2015, 23347); D.J. Galbreath and J. McEvoy, "How Epistemic Communities Drive International Regimes: the Case of Minority Rights in Europe" 35 Journal of European Integration (2013), 169-86; for an application of the notion by P. Haas himself, see P. Haas, "International Environmental Law: Epistemic Communities" in D. Bodansky, J. Brunée and E. Hey (eds), The Oxford Handbook of International Environmental Law (OUP, 2007), 791-806.

64 E. Adler, Communitarian International Relations: The Epistemic Foundations of International Relations (Routledge, 2005), at 15.

65 Ibid., at 15.

66 Ibid., at 17.

67 Ibid., at 14.

68 Ibid., at 14. 
considered one of the most elementary tools that allows social practice within the community. ${ }^{69}$

Third, international lawyers have found in literary and linguistic philosophy the notion of interpretive community. The concept does not need to be spelled out at length as it is further discussed later in this book. ${ }^{70}$ It suffices to recall that the notion refers to the public and conventional point of view that orders and principles the argumentative practice of international law and constrain the production of meanings. ${ }^{71}$ It presupposes a common understanding of what constitutes valid practice, such an understanding being occasionally translated into rules, like rules on interpretation or rules on sources of law. ${ }^{72}$ According to that notion, international lawyers constitute an interpretive community as soon as they share a language which allows them to speak to one another and a system of principles that each of them has internalized and which comes to constrain the type of legal argumentation they recognize as valid. ${ }^{73}$ Like the concept of community of practice, the notion of interpretive community is not fixed or finite. ${ }^{74}$ Because of both its ordering and anti-indeterminacy virtues as well as its fluidity, it is not surprising that the concept of interpretive community has enjoyed a resounding success in international legal scholarship. ${ }^{75}$

69 H. Cohen, "Finding International Law, Part II: Our Fragmenting Legal Community" 44 NYU Journal of International Law and Politics (2012) 1049.

70 See below chapter 7 on interpretation.

71 S. Fish, "Fish v. Fiss" 36 Stanford Law Review (1984) 1325-47, at 1331-2. S. Fish, Is there a text in this class? (Harvard University Press, 1980), pp. 13-14.

72 For a challenge of the idea that rules on sources constitute rules properly so-called, see J. d'Aspremont, "The Idea of Rules in the Sources of International Law”, 84 British Yearbook of International Law (2014) pp. 103-30.

${ }^{73}$ S. Fish, Is there a text in this class? Harvard University Press, 1980, at 5 .

74 S. Fish, "Fish v. Fiss" 36 Stanford Law Review (1984) 1325-47, 1329; see also S. Fish, Is there a text in this class? Harvard University Press, 1980, at 172. ("Of course, this stability is always temporary (unlike the longed for and timeless stability of the text). Interpretive communities grow larger and decline, and individuals move from one to another; thus, while the alignments are not permanent, they are always there, providing just enough stability for the interpretive battles to go on, and just enough shift and slippage to assure that they will never be settled.')

75 A. Bianchi, "The International Regulation of the Use of Force: The Politics of Interpretive Method" 22 Leiden Journal of International Law 2009, 665; J. d'Aspremont, "Wording in International Law", 25 Leiden Journal of International Law (2012) 575-602; I. Johnstone, "Treaty Interpretation: The 
Fourth, the community of international lawyers has also been apprehended by the idea of a shared platform of communication. According to this conceptualization, which has been deemed "communicative", 76 there is a community of international lawyers as soon as there is a striving for a shared vocabulary that allows communication and argumentation among scholars. Short of any communicative tool, international legal scholars cannot constitute a community of international law. This approach acknowledges that the shared vocabulary of the community is bound to be ever changing and fluctuate constantly. ${ }^{77}$ Yet, it is this striving that creates the possibility of communication necessary for the

Authority of Interpretive Communities", 12 Michigan Journal of International Law 371 (1990-1991); E. Papastavridis, "Interpretation of Security Council Resolutions under Chapter VII in the Aftermath of the Iraqi Crisis", 56 International and Comparative Law Quarterly (2007) 83-118; A. Bianchi, "Textual interpretation and (international) law reading: the myth of (in)determinacy and the genealogy of meaning", in: P.H.F. Bekker/R. Dolzer/M. Weibel (Hrsg.), Making Transnational Law Work in the Global Economy. Essays in Honour of D. Vagts, Cambridge 2010, 34 ss., 51 ss.; D.F. Vagts, "Treaty Interpretation and the New American Ways of Law Reading", in: EJIL, Vol. 4, Nr. 1, 1993, 472 ss., 480 ss.; F. Zarbiev, "Le discours interprétatif en droit international: une approche critique et généalogique" (Geneva: Graduate Institute of International and Development Studies, PhD thesis, 2009), 98 ss.; V. Fikfak/ Benedict Burnett, "Domestic Court's Reading of International Norms: A Semiotic Analysis", in: International Journal for the Semiotics of Law, Vol. 22, Nr. 4, 2009, 437 ss.; I. Johnstone, "Security Council Deliberations: The Power of the Better Argument", in: EJIL, Vol. 14, Nr. 3, 437 ss., 439.

76 See J. d'Aspremont, "Wording in International Law" 25 Leiden Journal of International Law (2012) pp. 575-602. See also chapter 1 in J. d'Aspremont, Formalism and the Sources of International Law (OUP, 2011). It is no coincidence that T. Meyer has interpreted this work as seeking to preserve the possibility of communication and calling for a new theory of communication in international law. See T. Meyer, "Towards a Communicative Theory of International Law", Melbourne Journal of International Law (2013) 1.

77 In the same sense, see A. Marmor, "Can the Law Imply More than It Says? - On Some Pragmatic Aspects of Strategic Speech", (December 3, 2009). USC Law Legal Studies Paper No. 09-43. Available at SSRN: http://ssrn.com/ abstract $=1517883$, p. 14 . There is "a certain degree of uncertainty about the relevant maxims of conversation or the level of adherence to them, that the parties are presumed to follow. It is precisely this lack of complete certainty about the maxims of conversation that enables the success of communication in spite of certain divergence of communicative expectations or intentions. The lack of certainty leaves certain content hanging in the air, as it were, leaving each party to the conversation with an option of understanding the full communicated content somewhat differently". 
subsistence of the community of international law. Such a conceptualization has simultaneously come with a plea for a renewed idea of the sources of international law - deemed necessary to allow communication $^{78}$ - that nonetheless ought to radically depart from the static pedigree-determining blueprints found in the mainstream literature. ${ }^{79}$ Such an understanding inevitably comes with its own self-created perils,${ }^{80}$ that is the hazard associated with a disaggregation of the language of the sources. ${ }^{81}$

All these cognitive models to apprehend the communitarian forces between the agents of international law have their own merits and weaknesses. It would be of no avail to try to evaluate each of them in the context of international law and determine which one offers the most useful construction of the community of professionals at work behind international law. It seems that each of them sheds light (and puts the emphasis) on a different - but equally relevant - aspect of the community of those socialized international lawyers. This is why the following chapters borrow from several of them, depending on the communitarian aspects of the foundational doctrines or argumentative techniques which

78 See contra the work of D. Davidson, "A Nice Derangement of Epitaphs", in D. Davidson, Truth, Language, and History (New York: Oxford University Press, 1986) 89-108 (for him conventions are not necessary to allow communication). See the discussion in I. Venzke, in "Is Interpretation in International Law a Game?" (May 23, 2014), forthcoming in: A. Bianchi, D. Peat and M. Windsor (eds), Interpretation in International Law (OUP, 2014), Amsterdam Law School Research Paper No. 2014-34, Amsterdam Center for International Law No. 2014-21, Postnational Rulemaking Working Paper No. 2014-02 as well as see more generally, I. Venzke, How Interpretation Makes International Law - On Semantic Change and Normative Twists (OUP, 2012).

79 J. d'Aspremont, Formalism and the Sources of International Law (OUP, 2011).

80 S. Singh, "Appendix 2: International Law as a Technical Discipline: Critical Perspectives on the Narrative Structure of a Theory" (May 26, 2013) in J. d'Aspremont, Formalism and the Sources of International Law (Oxford: OUP, 2013), pp. 236-61; University of Cambridge Faculty of Law Research Paper No. 22/2013.

81 This is a finding also made by H. Cohen, "Finding International Law, Part II: Our Fragmenting Legal Community", 44 NYU Journal of International Law and Politics (2012) 1049; see also J. d'Aspremont, "An Autonomous Regime of Identification of Customary International Humanitarian Law: Do Not Say What You Do or Do Not Do What You Say?" (March 8, 2013) in R. van Steenberghe (ed.), Droit international humanitaire: un régime spécial de droit international? 73 (Bruylant, 2013), available at SSRN: http://ssrn.com/abstract=2230345. 
they seek to elucidate. For the sake of the exploration attempted in the following chapters, there is no need to espouse a single uniform universalized and neat concept of community to make sense of the communitarian dynamics against the backdrop of which foundational doctrines and techniques are shaped and deployed.

There is another - probably more fundamental - reason why it would be vain to seek to elect a single model of community at work behind the foundational doctrines and argumentative techniques of international law under discussion in the following chapters. There is indeed not one community but a great variety of communities of international lawyers, each of them of different nature and subject to different structures. There seems to be no one to contest that the professional community organized around international law is fragmented and made of several different sub-communities at the same time. Such a pluralistic configuration originates in - often unconscious - differentiations, estrangements and federating dynamics of very different kinds: methodological, conceptual, political, linguistic, professional, cultural, geographical, etc. For the sake of this current study, it is certainly not necessary to provide a cartographic overview of the various sub-communities of international lawyers. Nor is it necessary to ascertain all the levels at which the community of international lawyers is fragmented. The point that must be made here, however, is that the foundational doctrines and the argumentative techniques examined here can, at times, be the very dividing and fragmenting factor. ${ }^{82}$ In that sense, the explorations that follow do not assume that the communitarian dynamics under examination are universal. They are generally those that can be observed in some of the dominant strands of the - mostly English speaking - international legal scholarship, that is among those international lawyers whose principal activity is of an academic nature.

82 Different communities, past and present, have different concepts of law, different foundational doctrines and different argumentative techniques. Among others, see L.B. Murphy, "Better to See Law this Way" 83 New York University Law Review (2008) 1104-8; F. Schauer, "Postivism as Pariah" in R.P. George (ed.), The Autonomy of Law: Essays on Legal Positivism (Clarendon Press, 1996) 31-56 at 34; J. Waldron, "Normative (or Ethical) Positivism" in J.L. Coleman (ed.), Hart's Postscript: Essays on the Postscript to The Concept of Law (OUP, 2001) 411-33; J. Beckett, "Behind Relative Normativity: Rules and Process as Prerequisites of Law" 12 EJIL (2001) 627-50, at 648. 


\section{SOCIAL VALIDATION IN THE COMMUNITY OF SOCIALIZED INTERNATIONAL LAWYERS}

As most of the following chapters point out, validation of legal arguments in this community of socialized international lawyers is itself of a social nature. Albeit contested, ${ }^{83}$ this does not seem to be particularly idiosyncratic. The concept of social validation has been extensively studied, in the theory of knowledge and literary philosophy ${ }^{84}$ and does not need to be discussed here. For the argument made here, what matters is to highlight that, against the backdrop of the social validation of legal arguments, a valid legal argument is primarily one that is received as such by the other members of the community. Said differently, the valid argument is the one that is successful, rather than the one that is ontologically valid. This applies to academics, judges and practitioners. ${ }^{85}$ This is not say that, because validation is social, acceptance is necessarily the unique criterion of validity. This does not mean that there cannot be procedural guarantees in the acceptance by the audience or in how the

83 See e.g. I. Venzke, "What Makes for a Valid Legal Argument? (Editorial)", 27 Leiden Journal of International Law (2014) pp. 811-16. Some critical remarks have also been formulated by V. Priuli in his presentation on "How States Frame the Legality of Secession. An Argumentation Analysis of the ICJ Advisory Proceedings on Kosovo" at the Amsterdam Centre for International Law in July 2014.

84 See T. Kuhn, The Structure of Scientific Revolutions, The University of Chicago Press, 50th anniversary edition, 2012. He famously argued that "paradigms gain their status because they are more successful than their competitors in solving a few problems that the group of practitioners has come to recognize as acute" (p. 24) and that there is no standard higher than the assent of the relevant community (p. 94). The same point is made by S. Fish, Doing What Comes Naturally, Duke University Press, 1989, 29-30 and 237. This has also been recognized by legal theorists. See e.g. C. Perelman, Justice, Law and Argument (D. Reidel Synthese Library, 1980), at 29.

85 For an examination of the the techniques used by courts to convince governments, legislature and the public, see G. Davidov and M. Davidov, "How Judges Use Weapons of Influence: The Social Psychology of Courts", 46 Israel Law Review (2013), 7-24. See also: L.V. Prott, "Argumentation in International Law", in: Argumentation, Vol. 5, 1991, 299 ss. and "The Style of Judgment in the International Court of Justice", in: Australian Yearbook of International Law, Vol. 5 (1970-1973), 1973, 75 ss. (applying the rhetorical theory of Perelman to the ICJ). 
consensus is reached. ${ }^{86}$ Social acceptance remains, however, in the view of the author of these lines, the primary validating parameter.

Social validation is complex. If an international lawyer is bound to convince her audience, it will be expected that she resorts to some of those foundational doctrines and argumentative techniques under discussion in the following chapters. However, it does not suffice to deploy the dominant foundational doctrines and argumentative techniques to secure social validation. First, because as will be shown in the chapters that follow, foundational doctrines and argumentative techniques are themselves very unstable, controversial, contested and the object of very diverging interpretations and practices. Moreover, the unprecedented growth of the community of international lawyers witnessed in the second half of the twentieth century ${ }^{87}$ as well as the turn to pragmatism and multidisciplinarity - as is witnessed in Anglo-American scholarship ${ }^{88}$ - makes validation all the more diffuse. It remains that, albeit more diffuse, the validation of legal argumentation remains primarily based on acceptance by the community of socialized international lawyers.

Claiming that validation of argumentation is social and hinges on acceptance by the community directly bears upon the nature of legal argumentation - and hence on the way foundational doctrines and argumentative techniques discussed in this book are designed and deployed. Indeed, those arguments are validated by virtue of their acceptance makes the operation of foundational doctrines and argumentative techniques essentially confrontational. ${ }^{89}$ Arguments are weapons ${ }^{90}$

86 See e.g. C. Perelman, Justice, Law and Argument (D. Reidel Synthese Library, 1980).

87 See the comments of J. d'Aspremont, "Wording in International Law" 25 Leiden Journal of International Law (2012), pp. 575-602.

88 For some critical remarks, see J. d'Aspremont, "Send Back the Lifeboats: Confronting the Project of Saving of International Law", 108 American Journal of International Law (2014) (forthcoming).

89 On the adversarial character of the legal arena and the extent to which such adversarial setting is determinative of the linguistic dynamics, see gen. D. Kennedy, "Theses about International Legal Discourse", 23 German Yearbook of International Law 353 (1980); M. Koskenniemi, "International Law and Hegemony: A Reconfiguration" (2004) 17 Cambridge Rev. Int'l Affairs 197 at 199. See also the remarks by I. Venzke, "Legal Contestation about 'Enemy Combatants' on the Exercise of Power in Legal Interpretation", 5 Journal of International Law and International Relations 155 (2009).

90 See A. MacIntyre, Whose Justice? Which Rationality, Duckworth, 1988, at 5 . 
and words are ammunition. ${ }^{91}$ Confrontation means that international lawyers are inextricably engaged in a struggle for persuasiveness. ${ }^{92}$ This confrontation pits groups against groups, schools against schools, generations against generations, ${ }^{93}$ and ultimately international lawyers against international lawyers. International law is thus a battle-ground where the international lawyer - even the nihilist - is necessarily an activist advocating a certain vision of the law and, hence, a given way to make sense of the world. According to this view, international law is a perpetual site of competition for persuasiveness in legal argumentation. ${ }^{94}$ In that sense, although the confrontational nature of international law is often disguised by a rhetoric of consensus, ${ }^{95}$ confrontation is the fate of international lawyers. 96

91 This whole process is why I have referred elsewhere to this confrontational dimension of legal argumentation through the idea of "wordfare". See J. d'Aspremont, "Wording in International Law" 25 Leiden Journal of International Law (2012) pp. 575-602.

92 P. Bourdieu: "The Force of Law: Toward a Sociology of the Juridical Field" (1987) 38 Hastings Law Journal 814-53, p. 838: "Law is the quintessential form of symbolic power of naming that creates the things named"; see also p. 837: "What is at stake in this struggle is monopoly of power to impose a universally recognized principle of knowledge of the social world".

93 This particular aspect of the confrontation has led A. Rasulov to claim that each generation comes to commit a certain kind of injustice against the preceding generation which is no longer there to defend its contentions. A. Rasulov, "New Approaches to International Law: Images of a Genealogy", in J.M. Beneyto and D. Kennedy (eds), New Approaches to International Law: the European and the American Experiences (TMC Asser-Springer, 2012), pp. 15191, 156. See also D. Kennedy who says that "Each generation considers the previous one naïve". See D. Kennedy, "Primitive Legal Scholarship", 27 Harvard Journal International Law Journal (1986), 1, at 7.

94 This does not mean that social validation and persuasiveness cannot work independently of one another. This is a point which I owe to I. Venzke.

95 This is not a phenomenon inherent in international law. See A. MacIntyre, Whose Justice? Which Rationality, Duckworth, 1988, p. 2.

96 J. d'Aspremont, "Wording in International Law" 25 Leiden Journal of International Law (2012) 575-602. See also S. Singh, "International Law as a Technical Discipline: Critical Perspectives on the Narrative Structure of a Theory" in J. d'Aspremont, Formalism and the Sources of International Law: A Theory of the Ascertainment of Legal Rules (2nd ed. OUP, 2013) 236-61; see also M. Koskenniemi who claims that international law "revels in adversity, not in consensus". M. Koskenniemi, "The Mystery of Legal Obligation", 3 International Theory (2011), 319-25, at 321. See also Koskenniemi: International Law in the World of Ideas (47 ff) at 47. 
It will not come as a surprise that, in this confrontational setting, social validation is very contingent upon a great variety of parameters: credentials, profession, nationality, origin, reputation, training, affiliation, repetition, proliferation, intense dissemination, footnoting, peer-referencing, moment of production, and linguistic aptitudes. These are usually among the criteria that determine whether an argument gains authority (and thus generates knowledge) or evanesces. As a result, it remains difficult to predict which idea will eventually survive and which international lawyer will be accordingly empowered with persuasiveness and semantic authority. The outcome of the struggle is uncertain and open-ended. It is true that institutional structures come to mitigate this open-endedness of the social validating process ${ }^{97}$ as confrontation unfolds in a strongly organized and hierarchical semantic and social system which is far from being egalitarian. There are hierarchies which are rarely acknowledged as such but which fundamentally impinge on how social validation unfolds. ${ }^{98}$ This does not suffice, however, to provide any sort of predictability as to which legal arguments will be socially validated.

It is important to note that the idea that the community of socialized international lawyers is essentially confrontational has been contested. It has been said that it puts too much emphasis on the adversarial setting and demotes international legal argumentation to an aggregation of competing claims. ${ }^{99}$ In that sense, it is objected that communitarian approaches such as the one put forward here manifest a certain disenchantment about the quest for validity and bring about too radical a move away from the argument itself. ${ }^{100}$ It does not leave any justification

97 See gen. A. Rasulov, "New Approaches to International Law: Images of a Genealogy", in J.M. Beneyto and D. Kennedy (eds), New Approaches to International Law: the European and the American Experiences (TMC AsserSpringer, 2012), pp. 151-91.

98 Customary international law and non-formal sources of law offer much more room for projections of power. On this aspect, see J. d'Aspremont, Formalism and the Sources of International Law (OUP, 2011), pp. 151-4 and 162-70.

99 N. Onuf, "Do Rules Say What They Do? From Ordinary Language to International Law”, 26 Harvard International Law Journal 385 (1985), at 393; see also I. Venzke, "Multidisciplinary Reflections on the Relationship between Professionals and The(ir) International Law" (December 4, 2013). ESIL 2013. 5th Research Forum: International Law as a Profession, Conference Paper No. 4/2013, p. 8 .

100 I. Venzke, "What Makes for a Valid Legal Argument? (Editorial)", 27 Leiden Journal of International Law (2014) pp. 811-16. 
as to why international lawyers should continue to argue. ${ }^{101}$ Many of these critiques - albeit not exclusively ${ }^{102}$ - find support in the work of Habermas who famously tried to qualify the idea that validity is nothing more than acceptance by testing the validity of arguments in argumentative practice itself. ${ }^{103}$

These weighty criticisms call for a remark with a view to nuancing the idea that validation of legal arguments is social. Indeed, it should be made clear that emphasizing the adversarial dynamics of the social validation of legal argument does not mean that there are no reference points other than social to assess the validity of argument. ${ }^{104}$ Nor does it entail an abandonment of internal determinants of legality. ${ }^{105}$ Securing persuasiveness and semantic authority lies primarily in the fluctuating balance of powers of the international legal scholarship. This does not exclude, however, that internal consistency of the argument plays a significant role in the validation process. This is precisely why this book focuses both on foundational doctrines and the argumentative techniques (including dissemination techniques). It is true that, as was already highlighted above, securing persuasiveness that is necessary for social validation is not only a matter of argumentation and debate. It is also a question of (the quality of) the substantive doctrines that are relied upon. In that sense, securing validation within the community of socialized international lawyers depends on both argumentation per se and, albeit to a lesser extent, the substance of the argument. It remains that, for the

101 Ibid.

102 It is worth noting that not all of this critique has been Habermasian. Some critique has been formulated by the so-called "Strukturierende Rechtslehre" on the basis of interdisciplinary research between jurisprudence and linguistics. See F. Müller/R. Christensen, Juristische Methodik, 2 Volumes, 9th ed., Berlin 2004 and F. Müller, Syntagma, Berlin, 2012. This was brought to my attention by V. Priuli.

103 It is interesting to note that Habermas has continued to enjoy a very solid appeal among German international lawyers. See more generally, I. Venzke, How Interpretation Makes International Law - On Semantic Change and Normative Twists (OUP, 2012). See also I. Venzke, "What Makes for a Valid Legal Argument? (Editorial)", 27 Leiden Journal of International Law (2014) (forthcoming). See M. Goldmann, "Principles in International Law as Rational Reconstructions. A Taxonomy" (November 13, 2013), available at SSRN: http://ssrn.com/abstract=2442027.

104 Contra I. Venzke, "What Makes for a Valid Legal Argument? (Editorial)", 27 Leiden Journal of International Law (2014) pp. 811-16.

105 For an attempt to preserve internal determinants of legality while acknowledging the role of external dynamics, see J. d'Aspremont, Formalism and the Sources of International Law (OUP, 2011). 
chapters that follow, what is perceived as internally consistent is itself a matter of perception by the community concerned.

\section{STRUCTURE OF THIS VOLUME}

This book is structured after the two-pronged and dialectical line spelled out above. It primarily examines the internal social arrangements sought by socialized international lawyers when they design and deploy the foundational doctrines and the argumentative techniques around which international law, as an argumentative practice, articulates itself. Needless to say that in its attempt to functionally and internally situate the design and deployment of foundational doctrines and argumentative techniques, this book cannot be comprehensive, let alone exhaustive. It only seeks to functionally and internally situate a carefully selected number of doctrines and argumentative techniques of international law.

The selection thereof is not entirely arbitrary, for it zeroes in on those foundational doctrines and argumentative techniques that are deemed, for the present author, the most prominent for both the socialization of international lawyers and the social validation of legal arguments. In other words, the selection of foundational doctrines and argumentative techniques has been carried out on the basis of the role which each of them plays both in terms of membership of the community of international lawyers (their mastery being an essential part of the socialization process) and in terms of their validating impact (a convincing argument requiring their deployment).

It should also be emphasized that the selection of foundational doctrines and argumentative techniques under examination has also been informed by a search for aesthetics. Too often, aesthetics of legal arguments are denied despite them being extremely conducive to social validation. This book does not conceal the role played by aesthetics in the choice of an equal number of foundational doctrines and argumentative techniques, each of them representing a distinct part of the book. The five foundational doctrines discussed here are subjects (chapter 1), sources (chapter 2), law-making (chapter 3), institutions (chapter 4) and effectivity (chapter 5). The five argumentative techniques examined here are methodology (chapter 6), interpretation (chapter 7), academic writing (chapter 8), dissemination (chapter 9) and expert blogging (chapter 10). It is noteworthy that the discussions on argumentative techniques include reflections on dissemination techniques as well. Although argumentation and dissemination must be distinguished, the two are sometimes so closely intertwined that it does not always seem possible to separate the 
two. This is why the discussions on the argumentative techniques in Part II include reflections on dissemination, academic writing and expert blogging.

It is conspicuous that many of these chapters are intertwined. Overlaps should certainly not be excluded or denied. For instance, all foundational doctrines have been designed as a result of certain methodological moves or have been generated through interpretive processes. Foundational doctrines have also established themselves as a result of writing and disseminating tactics. Foundational doctrines also overlap with one another. Law-making and sources are - respectively dynamic and static modes of cognition of the same phenomenon. Likewise, the doctrine of subject has always been informed by (and constituted an offspring of) the doctrine of effectivity. Interconnections and overlaps exist between argumentative techniques as well. It suffices to mention methodology and interpretation or writing and dissemination. Examples of overlaps could be multiplied ad infinitum and it does not seem necessary to elaborate on that. It seems more noteworthy to emphasize that such interconnections underpin the idea - on which this book is premised - that all these foundational doctrines and argumentative techniques contribute to the very same socialization process.

It is true that it is not always possible to distinguish between techniques and foundational doctrines. There may be a thin line, especially in the eyes of practitioners. Such hesitations could arise in the sources of international law (which is here examined as a foundational doctrine) or interpretation (which is here examined as an argumentative technique). ${ }^{106}$ In that sense, there is an inevitably normative choice behind the branding of each of the ten following areas of legal argumentation as either a foundational doctrine or an argumentative technique. It is accordingly important to stress that foundational doctrines are understood here in the sense in which German scholars use their term "Dogmatic", that is, a coherent set of propositions articulated around rules and case-law which are produced by discourses involving both practice and legal scholarship. ${ }^{107}$ Argumentative techniques, for

106 The following branding of interpretation as a technique concurs with that of D. Bederman. See D. Bederman, The Spirit of International Law, The University of Georgia Press, 2002, at 70.

107 On the idea of Dogmatic see M. Goldmann, "Principles in International Law as Rational Reconstructions. A Taxonomy" (November 13, 2013), available at SSRN: http://ssrn.com/abstract=2442027) who relies on the definition by R. Alexy. R. Alexy defines Dogmatic as "(1) a set of propositions; (2) which refer to legal rules or case law, but which are not identical with them; (3) which are 
their part, are understood as sets of craftmanship which are deployed by international lawyers when building and communicating their legal arguments.

The foundational doctrines under examination which are deemed to be most instrumental in the social validation of legal arguments as well as the socialization of scholars are statehood, sources, law-making, organization and effectivity. We could discuss at length this choice. It probably is self-evident that this choice is much informed by a continental approach to international law. From an Anglo-American perspective, the emphasis would probably have been given to other doctrines, like legitimacy or compliance. ${ }^{108}$ Even from a continental perspective, other foundational doctrines could have obviously been included. One may think of responsibility, territory, personality or jurisdiction. ${ }^{109}$ The exercise attempted here could thus be pursued in connection with other doctrines. However, such an obvious finding is certainly not alien to the agenda of the author of the chapters that follow. It seems that there still is much critical reflection necessary when it comes to internal functional situationalism in international law. Albeit to a lesser extent, the foregoing also holds for the choice of the argumentative techniques examined here.

Notwithstanding the normative choices informing how foundational doctrines and argumentative techniques are distinguished, it is true that there seems to be a certain agreement across all traditions of international law as to what the main argumentative techniques of international law are. That methodology, interpretation, writing, dissemination, and - more recently - blogging, boil down to core techniques of argumentation does not seem contested. This even seems to reflect some cross-cutting

coherent with each other; (4) which are constructed and administered by a professional elite including judges, public servants and legal scholars; (5) and which have a normative character" (p. 5) (R. Alexy, Theorie juristischen Argumentation (2d ed., Suhrkamp Verlag Gmbh, 1991), 314.

108 On the turn to legitimacy and compliance in the Anglo-American legal scholarship see J. d'Aspremont, "Send Back the Lifeboats: Confronting the Project of Saving of International Law", 108 American Journal of International Law (2014) (forthcoming).

109 As far as jurisdiction is concerned, I must confess that I have never understood how, in mainstream international legal scholarship, this came to be elevated into a doctrine in the first place. First, because what international lawyers identify as grounds of jurisdiction are nothing more than convergences of practices of domestic judges. Second, and more fundamentally, it does not seem that, in the mainstream understanding of international law, there is room for any allocation of competences by international law to domestic authorities. This conceptual contradiction in mainstream scholarship seems to go unnoticed. 
consensus in social sciences regarding what it means to build knowledge. It remains that the distinctions made here rest on some normative choices which should not be denied and which peers and colleagues will certainly relish deciphering, deconstructing and critiquing. 